\title{
Linda Babcock: Go-getter and Do-gooder
}

\section{Citation}

Bazerman, Max H., Iris Bohnet, Hannah Riley Bowles, and George Loewenstein. "Linda Babcock: Go\#getter and Do\#gooder." Negotiation and Conflict Management Research 11, no. 2 (2018): $130-45$.

\section{Permanent link}

http://nrs.harvard.edu/urn-3:HUL.InstRepos:38478350

\section{Terms of Use}

This article was downloaded from Harvard University's DASH repository, and is made available under the terms and conditions applicable to Open Access Policy Articles, as set forth at http:// nrs.harvard.edu/urn-3:HUL.InstRepos:dash.current.terms-of-use\#OAP

\section{Share Your Story}

The Harvard community has made this article openly available.

Please share how this access benefits you. Submit a story.

\section{Accessibility}




\title{
Linda Babcock: Go-getter and Do-gooder
}

Max Bazerman ${ }^{1}$, Iris Bohnet ${ }^{1}$, Hannah Riley Bowles ${ }^{1}$, and George Loewenstein ${ }^{2}$

Keywords: Negotiations, Self-serving bias, Gender in negotiations, Gender and nonpromotable tasks

Correspondence: George Loewenstein, Department of Social and Decision Sciences, Carnegie Mellon University, Pittsburgh, PA 15213, U.S.A.; email: GL20@andrew.cmu.edu

\begin{abstract}
In this tribute to the 2007 recipient of the winner of the Jeffrey Z. Rubin Theory-To-Practice Award by the International Association for Conflict Management (IACM), we celebrate Linda Babcock's contributions to diverse lines of research, her tireless and effective efforts to put the insights of her research into practice, and, at a personal level, the impact she has had on each of our lives. Innovative ideas and novel methods have been the hallmarks of Linda's research on diverse topics: the impact of self-serving conceptions of fairness on negotiations, the labor supply behavior of cab drivers, the impact of damage caps on settlements, the propensity of men and women to initiate negotiations, and the readiness of each gender to volunteer for, and work on, 'non-promotable tasks'. Linda won this award, however, not only for her path-breaking academic research, but for her interest in, and ability to, convert it into actionable initiatives, From founding the Program for Research and Outreach on Gender Equity in Society (PROGRESS), whose mission is to develop tools to teach women and girls how to harness the power of negotiation to her leadership of the Carnegie Mellon Leadership and Negotiation Academy for Women, Linda shows how academics can play a leading role in translating theory into practice.
\end{abstract}

${ }^{1}$ Harvard University, Cambridge, MA, U.S.A.

${ }^{2}$ Carnegie Mellon University, Pittsburgh, PA, U.S.A. 
In a recent paper titled “Do-gooders and go-getters," LSE professors Nava Ashraf and Oriana Bandiera report results from a field experiment addressing the question of whether there is a positive or negative relationship between being nice and being ambitious. Are warmth and competence complements or substitutes? Linda Babcock is a prominent data point consistent with their finding that niceness and success go hand-inhand. Linda, the recipient of the IACM Jeffrey Rubin Theory to Practice Award in 2007 was a perfect choice exactly because she has channeled her academic talents - her go-getter side -- so artfully into practice - into "doing good." The fact that all four of us were anxious to be part of the tribute to her is a testament to Linda's academic achievements, her gogetter side. However, equally and possibly even more importantly, we cherish Linda for her warmth. She has been a close friend to each of us. Here, we review some of the main phases of Linda's research, at times weaving in personal reflections.

\section{Pre-behavioral years}

As a graduate student, Linda studied conflict in the style of the labor economics of the time. Already interested in why negotiations go awry, and an expert in econometrics, she used archival data to explore the causes of labor impasses - looking at factors such as arbitrator uncertainty, social comparison processes, and uncertain beliefs. Although she was not yet a card-carrying behavioral economist at the time, there are strong hints of her later behavioral focus in her early work. For example, consider the opening of the abstract from her 1992 paper with Craig Olson (Babcock \& Olson, 1992) on the causes of impasses in labor disputes:

Using data on teacher contract negotiations under final-offer arbitration, this paper investigates the causes of impasses in contract negotiations and finds some support for each of three perspectives: game-theoretic, psychological, and political.

In the paper, Babcock and Olson highlighted that management and union negotiators might fail to reach an agreement due to the desire to blame the outcome on a third party - the arbitrator -- when they couldn't deliver a result good enough to please their constituents, even if the expected value of the result of arbitration was worse than the agreement they had, or could have, negotiated. Being able to blame the judgment of the arbitrator solved a political problem for the negotiator. The paper's abstract continues:

... negotiators frequently wish to avoid the political costs of a compromise settlement, preferring to blame arbitrators for the outcome.

And there are, as well, hints of an early awareness of, and interest in, self-serving bias. The abstract concludes:

The positive correlation between the probability of an impasse and the variance in comparable negotiated settlements suggests that the parties base their judgments of fairness using evidence most consistent with their own position. 
Linda never lost her interest and expertise in traditional economics, as evidenced by a steady stream of non-behavioral publications (e.g., Babcock, Benedict \& Engberg, 1998; Babcock, Engberg \& Glazer, 1997; Babcock, Engberg \& Greenbaum, 2005; Babcock \& Taylor, 1996). However, as her first paper, with Olson, suggests, when Linda began her first faculty position at Carnegie Mellon University, the behavioral insights were waiting to jump out. Her position at famously interdisciplinary CMU allowed her to escape the constraints of the assumptions of her traditional training, to diversify into experimental methods, and to emerge as a leading scholar, first on biases in negotiation (most specifically the role of self-serving interpretations) and later on the diverse ways in which women and men differ in negotiations.

\section{Self-serving bias and bargaining impasse}

Early in her academic career Linda was best known in the negotiations scholarly community for her work on self-serving biases in negotiations. Teaming up with George Loewenstein at CMU (a coauthor of this piece) as well as Colin Camerer and Sam Issacharoff, Linda coauthored research on the self-serving bias in negotiations - the tendency, as Linda had expressed it in the paper with Olson, for "parties [to] base their judgments of fairness using evidence most consistent with their own position" as quoted above.

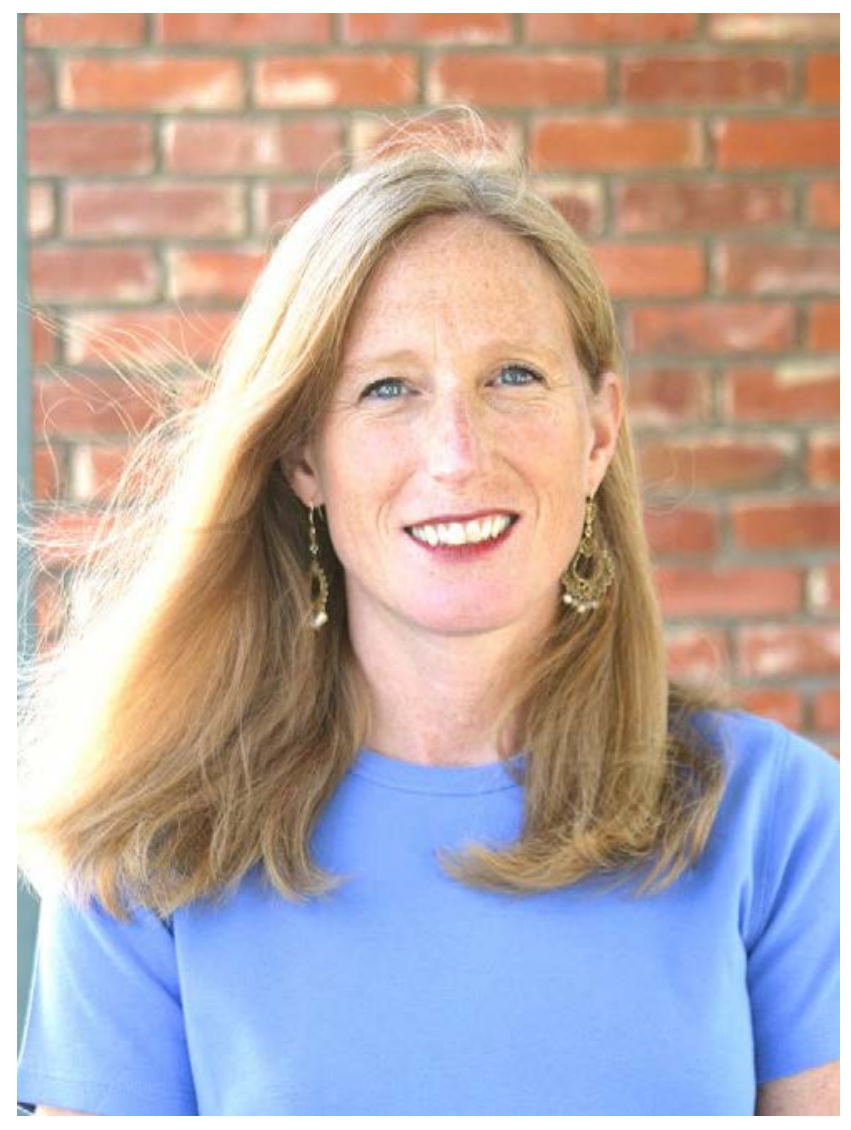

Figure 1: Linda Babcock, 2008 (photo taken for Ask For It book cover) 
In their first paper on the topic, Linda and colleagues developed a unique experimental paradigm they titled "Sudden Impact" - based on a real law case in Texas (Issacharoff was, at the time, a law professor at the University of Texas) resulting from an accident in which an automobile driver, Johnson, hit a motorcyclist, Jones, who sued Johnson for damages. The case was distilled to 27 pages of materials, including depositions from plaintiff Jones (the motorcyclist) and defendant Johnson (the driver), expert reports and diagrams of the crash. Experimental subjects were paired, assigned to the role of plaintiff or defendant, and attempted to negotiate a settlement of the case.

This was not just a role-playing exercise. The two parties had a real incentive to immerse themselves in the case, in part because they were informed that if they failed to settle the ruling of an actual judge who had read the case materials would determine the outcome of the case, so their best alternative to a negotiated settlement was their prediction of the judge's ruling, minus legal costs that were imposed if the parties failed to settle. They were also motivated to read the case materials carefully because they were asked, prior to negotiating, to predict the ruling of the judge and rewarded for guessing it accurately. The case, therefore, incorporated a rich context, but one that mattered to the participants in ways that paralleled incentives to the original parties in the case. This may have been the first study, and is still one of a small handful of studies, to incorporate context into an experiment in an incentive compatible fashion.

In an initial paper using the case (Loewenstein, Issacharoff, Camerer \& Babcock,, 1993), published in the Journal of Legal Studies, Linda and co-authors showed that subjects did exhibit a self-serving bias: With a possible range of $\$ 100,000$, plaintiffs guessed that the judge's ruling would be about $\$ 14,500$ higher than defendants guessed it would be. Moreover, the difference between the two parties' guess of the judge, which corresponded closely to their notions of what would be a fair settlement (because they expected the judge to share their perspective), was a powerful predictor of non-settlement. Pairs for whom the difference between their predictions of the judge was greater than the median were 10 times more likely to impasse than those whose self-serving bias was below the median. The paper also asked both parties to recall arguments from the case favoring the role they were playing as well as arguments favoring the other party, and again a self-serving bias was observed (which predicted the self-serving bias in predictions of the judge); the two parties appeared to sift through the case materials in a selective fashion that favored their own position.

A limitation of this first study was its correlational nature; self-serving bias did predict non-settlement, but the experiment could not establish that the self-serving bias caused impasse; it was also possible that, for example, nastier negotiators were both more likely to exhibit self-serving bias and be more prone to impasse. Linda came up with a clever solution to this problem, which the team implemented in the next study. Exploiting the finding that the self-serving bias emerged from biased processing of case materials, pairs of subjects were randomly assigned to read through the case materials either before or after being informed of their role in the negotiation. Subjects who were assigned only after they had read the case materials, who could not sift through them in a biased fashion because they didn't yet know their role, were predicted and found to exhibit a smaller selfserving bias. More importantly, and, consistent with causality running from self-serving bias to impasse, they were much less likely to settle the case. This study (Babcock, 
Loewenstein, Issacharoff \& Camerer, 1995) was published in the American Economic Review.

Linda's other most important papers on self-serving bias accomplished two goals. The first tested different ways of promoting settlement by debiasing self-servingly biased disputants. One intervention, which had no discernible impact, was to inform subjects about the existence and consequences of the self-serving bias (and to give them a quiz to make sure they had understood what they were told). Another, which not only failed to produce the desired effect, but backfired to some extent, instructed each disputant to articulate their counterpart's perspective. To explain why the intervention failed, the authors speculated that, as a result of self-serving bias, disputants had difficulty articulating their counterpart's perspective, and attributed the difficulty of doing so not to their own bias but to the weakness of their counterpart's position. A different intervention, in which disputants were instructed to list weaknesses of their own case, did, however, succeed in reducing the magnitude of the self-serving bias and in promoting higher levels of settlement. In this paper one can catch an early glimpse of Linda's interest in using research findings to generate practical solutions to problems.

The other goal, which the next paper accomplished, was to demonstrate the consequence of the self-serving bias in a field setting. In a field study reported in a paper with graduate student Xianghong Wang, and Loewenstein, Linda sent letters to the presidents of all 500 school boards in the state of Pennsylvania, as well as to all heads of local teachers' unions. The surveys asked each respondent to provide a list of the school districts that they viewed as 'comparables' - i.e., as most relevant points of reference for their current negotiation.

Both central predictions of the study were borne out. First, although both sides listed, on average, the same number of comparable districts, salaries in the towns that the school boards viewed as "comparable" were on average approximately $2.4 \%$ lower than salaries in the towns that unions viewed as comparable (the average salary increase at this time was about $5 \%$ per year). Second, the magnitude of the difference between the average salaries in the two parties' lists of comparable towns predicted the occurrence of a teacher's strike. Point estimates from regression analysis suggested that when the salary of the union's list was $\$ 1,000$ greater than that of the school board, there was a $49 \%$ increase in the likelihood of a strike as compared to when the salaries in the two lists were equivalent. This was one of the first field studies in behavioral economics, a field in which field studies have subsequently become commonplace.

Linda also played a key role, applying her econometric skills, in a second field study that has become a classic in the field of behavioral economics (Camerer, Babcock, Loewenstein, \& Thaler, 1997), on "labor supply of New York City cab drivers". Cab drivers face high wage days (e.g., when it is raining or there is an event that brings lots of people into the city) and lower wage days (e.g., when the weather is nice and many people decide to walk), and many have a choice of how long to work - when to quit. Standard labor economics, as well as simple logic, makes a simple prediction: drivers should work longer on high wage days than on low wage days. Linda and her collaborators predicted, and found, however, that drivers displayed the opposite pattern, consistent with the idea that they were "income targeting." Just income targeting alone would not have resulted in the observed pattern; to get it, cab drivers had to be targeting at the day level - to want to make at least a fixed amount each day (as opposed to, for example, the week level, which, 
the authors showed, would not have resulted in the observed pattern). A tribute to both its novelty and controversiality, the paper initiated what has come to be a virtual cottage industry of studies examining cab drivers' (and more recently Uber driver's) behavior.

At around the same time, Linda also did important behaviorally informed experimental and field research on the impact of state-legislated damage caps in medical malpractice suits. Several states had introduced caps on malpractice awards in an attempt to shield doctors from liability, reduce medical costs and reduce the prevalence of unjustified "nuisance suits" in a domain of legislation notorious for both Type I errors (the initiation and success of frivolous, unjustified suits) and Type II errors (the failure to bring suits where they were warranted by real medical mistakes). Linda's work with graduate student Greg Pogarsky may have played a role in decelerating the introduction of such legislation. Their research showed that the caps had the effect not only of lowering awards that in their absence would have been higher, but also the perverse effect of increasing the magnitude of awards that in the absence of damage caps would have been lower.

\section{Women don't ask: The role of gender in the initiation of negotiations}

A second important line of Linda's research has been on the role of gender in negotiations. The IACM Rubin Theory-to-Practice Award recognizes scholars who "bridge research and practice, and either change practice or inspire theory and research." Linda's work on gender in negotiation has done all of the above. In her work on the subject of gender in negotiation, Linda has been an intellectual provocateur, academic community builder, and public champion for women to assert themselves and succeed as negotiators.

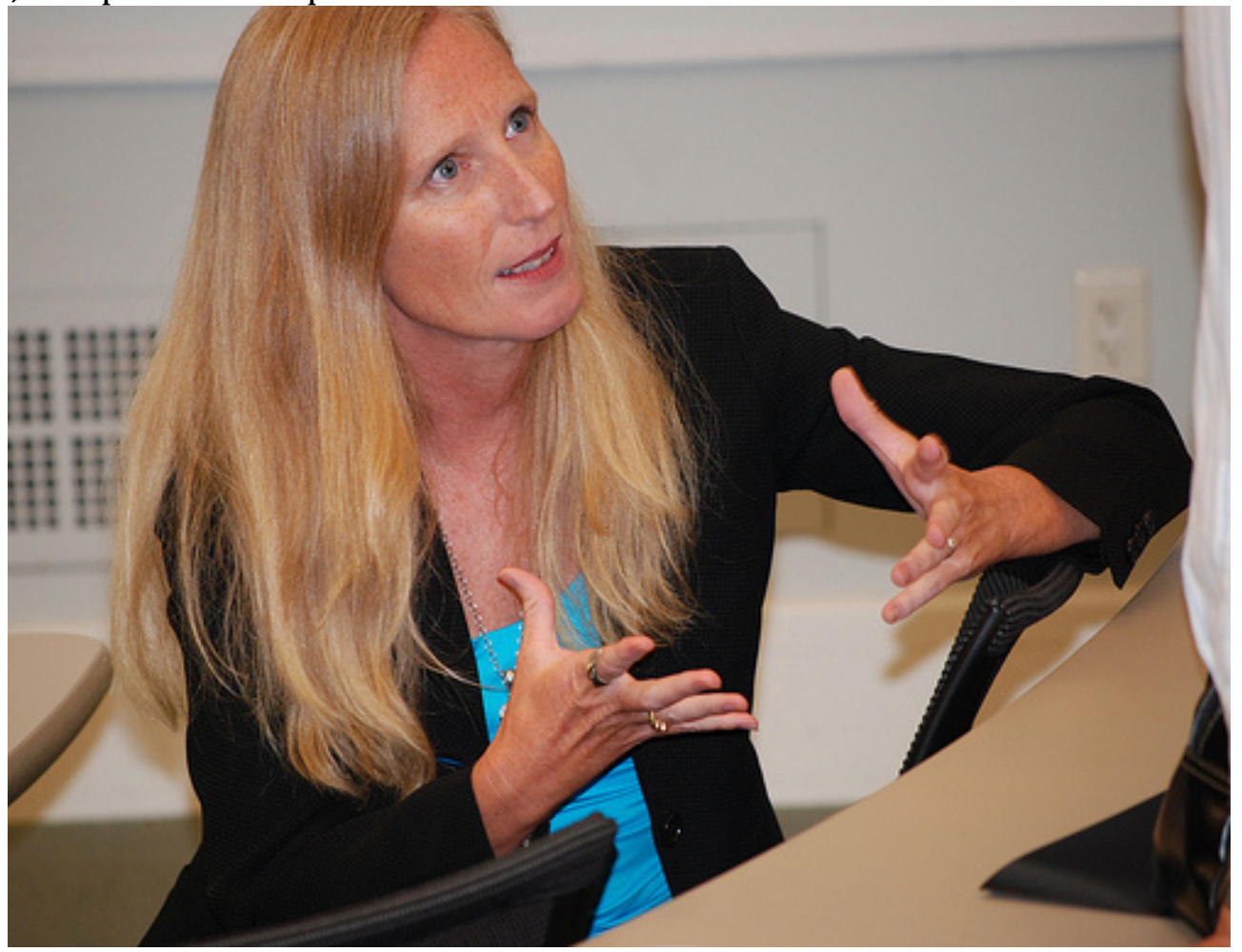

Figure 2: Linda at Carnegie Mellon Leadership and Negotiation Academy for Women 
Prior to Linda's work on gender in negotiation, the literature focused on dependent variables such as value claiming, value creation, or profitability of the negotiator, typically only finding weak and sometimes, inconsistent effects. Linda's brilliance starts with the observation that the literature was not looking at all the relevant dependent variables.

In preparing her best-selling book Women Don't Ask: Negotiation and the Gender Divide (2003), Linda partnered with professional writer, Sara Laschever, to craft a scholarly book that would wake up academic and popular audiences to women's handicaps as negotiators and their important social and material consequences. The notion that "women don't ask" first dawned on Linda when she was Chair of the PhD Program at Carnegie Mellon's Heinz School of Public Policy and Management. In an experience that planted the idea in her head and which Linda and Sara opened Women Don't Ask with, a group of female doctoral students complained to Linda that their male peers were teaching their own courses while they were still languishing as teaching assistants. Investigating the claim, Linda discovered it was true, and initially suspected discrimination. Further sleuthing, and a conversation with the associate dean in charge of teaching assignments, however led to a different conclusion that became the core of her book. The problem was, the associate dean reported, that, “'More men ask. The women just don't ask"” (p. 1).

Linda and Sara motivate the book with this provocation: "Could it be that women don't get more of the things they want in life in part because they don't think to ask for them?" (p. 1). To explore this question, Linda began talking to women about their inhibitions as negotiators. She stretched herself to master new literatures-including auditing a CMU colleague's course on social cognition. She also began forming a new community of research collaborators.

Diverging from her prior proclivities as a strictly quantitative researcher, Linda launched the first edition of Women Don't Ask based mainly on conversations with scores of women about their missed and failed opportunities to negotiate. The book not only found an eager readership from the many women who could relate to its message, but also excited scholars' curiosity about why women would be more inhibited negotiators than men. Potential explanations included the possibility that women (as compared to men) have a weaker sense of control over their environment (e.g., see Sherman, Higgs, \& Williams, 1997) and might, therefore, be less likely to recognize opportunities for negotiation. As Linda and Sara (2003) put it, women might be more likely than men to adopt the perspective that "you can't get blood from a turnip"' than to "see the world is your oyster'" (p. 19). They speculated that feminine gender roles (Eagly, 1987) and a lack of entitlement (Major, McFarlin, \& Gagnon, 1984) might constrain women's aspirations and or lead them to concede too early. Finally, there was the possibility that women were simply afraid of negotiating, due to personal anxiety, conflict avoidance, the need to retain powerful sponsors (Burt, 1998), risk aversion (Byrnes, Miller, \& Schafer, 1999), or appearing too brash (Rudman, 1998). In the concluding chapter, they tried to encourage women by highlighting how stereotypic female advantages in relationship management and cooperation could work to their advantage (cf., Curhan, Neale, Ross, \& RosencranzEngelmann, 2008). 


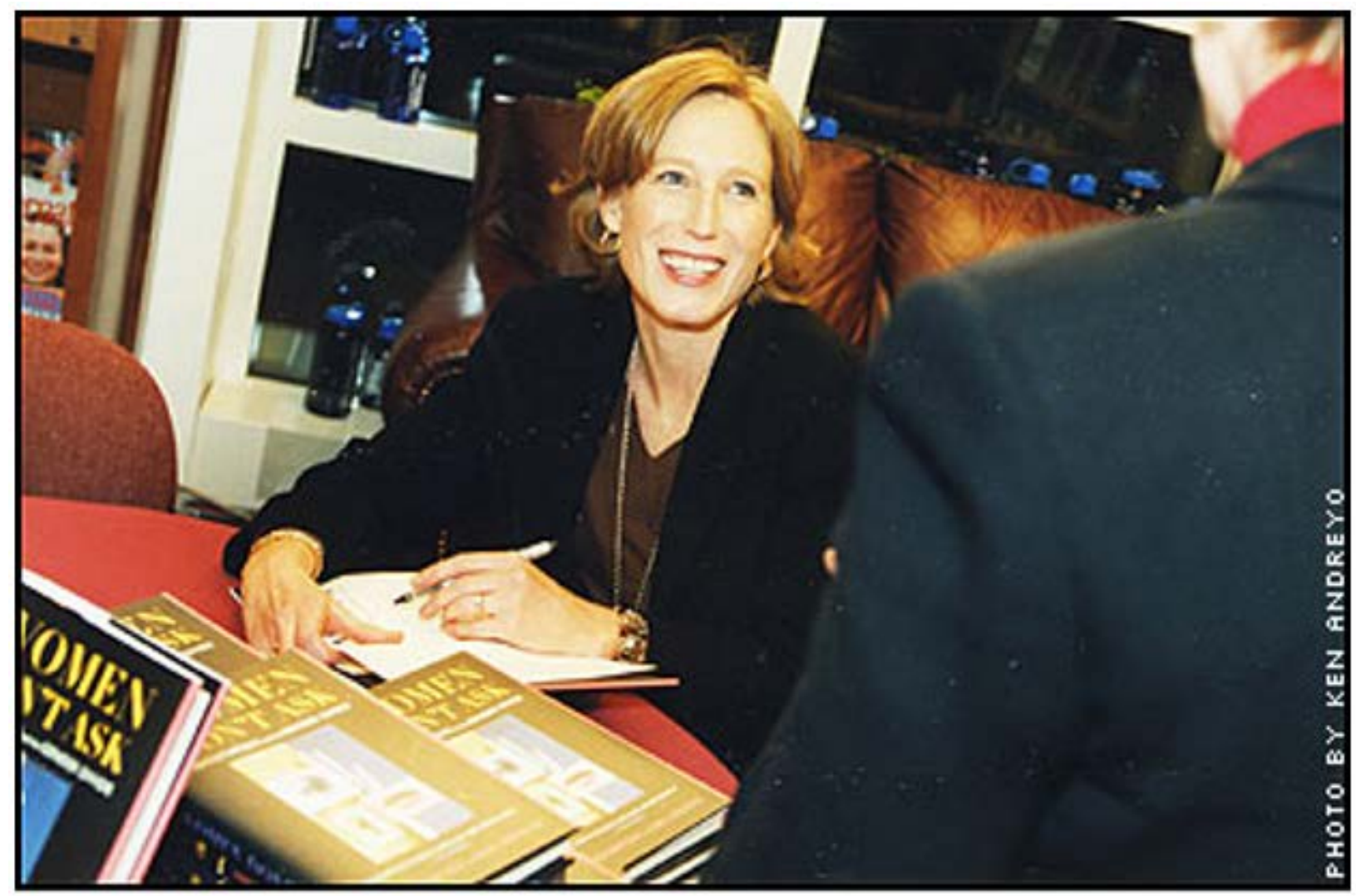

Figure 3: Linda Babcock signs copies of her book "Women Don't Ask" at the Carnegie Mellon University bookstore, 2003

When Linda was first contemplating the idea that "women don't ask," she attended an IACM conference presentation by University of Maryland Professor Michele Gelfand about the propensity to negotiate. As Michele recalls it, Linda came up to her after the talk and said, "We need to get a beer-right now." From that spirited conversation stemmed a collaboration, which, along with Carnegie Mellon doctoral students Deborah Small and Heidi Stayn and University of Maryland doctoral student Hilary Gettman, produced the first quantitative studies on gender and the propensity to initiate negotiation (PIN). Babcock, Gelfand, Small, and Stayn (2006) started by publishing a survey asking men and women about the last time that they negotiated. On average, men reported " 7 days" as compared to "30 days" for women. When asked when they anticipated negotiating next, the answer was the same: next week for men and next month for women. In support of the "turnip" vs. "oyster" hypothesis they found that men appeared to negotiate more often, in part, because they were more likely to recognize opportunities to do so.

In follow-on experimental research, Small, Gelfand, Babcock, and Gettman (2007) devised a novel paradigm for negotiation research in which participants had the potential to negotiate for higher compensation for their work in the study. The primary dependent measure was whether they asked for higher pay. Small et al. (2007) recruited participants to play Boggle, a game in which they established there were no gender differences in performance. Then they cued them subtly that there was potential negotiation (i.e., "'Here's 
\$3. Is $\$ 3$ OK?"'), or they said explicitly that they could "negotiate" or "ask" for higher pay. They found that the framing of the potential to negotiate had a significant effect on women's propensity to negotiate. When cued subtly, only a minority of men negotiated their pay (i.e., $13 \%$ in Study 1, 25\% in Study 4), but it was an even smaller minority of women (i.e., $0 \%$ in Study 1, 4\% in Study 4). When men and women were told explicitly they could "negotiate," the majority of participants negotiated but women still negotiated less often than men. Somewhat ironically, when men and women were told they could "ask" for more pay, women asked as often as men.

Small et al. (2007) theorized that "negotiation" (as compared to "asking") is perceived as a higher power behavior and is, therefore, less threatening to men than women because men tend to hold higher power in society. When they manipulated the psychological experience of power, they found again that gender differences in PIN diminished (see also Magee, Galinsky, \& Gruenfeld, 2007). In addition to the PIN findings and novel experimental paradigm, this research contributed to a growing body of evidence that gender effects in negotiation are situational rather than personality based (Bowles, Babcock, \& McGinn, 2005; Kray \& Babcock, 2006; Kray \& Thompson, 2004; Walters, Stuhlmacher, \& Meyer, 1998).

When Linda was developing her book ideas, she took a visiting position at Harvard Business School and met Hannah Riley Bowles, one of the authors of this piece who was pursuing a dissertation on multi-party conflicts under the supervision of Kathleen McGinn. Hannah challenged a major implication of Linda's book, that women would do better if they "asked" more often - questioning whether it was possible that women didn't assert themselves as much as men in negotiation because they would experience social backlash if they did so (see Rudman, 1998). One of Linda's remarkable, and all too rare, qualities is that she is genuinely involved in a search for truth. Rather than resisting the possibility of a conclusion that could challenge the results she proposed in her book, she responded reflexively to this, as she would to any question or theoretical challenge with, "Let's test it!" Linda's passion was to help women to raise their aspirations and to negotiate more effectively, and she was ready to pursue the research in whatever direction it would go to accomplish these goals.

Linda's collaboration with Hannah led to a series of publications illuminating when gender effects emerge in negotiation (Bowles et al., 2005), why women were more inhibited than men about negotiating (Bowles et al., 2005), and how women can evade gender-stereotype-based traps in negotiation (Babcock, Bowles, \& Bear, 2012; Bowles, Babcock, \& Lai, 2007). Building on Hannah's dissertation, Bowles et al. (2005) presented evidence of two categories of situational factors that influence gender effects in negotiation: 1) "structural ambiguity" (i.e., lack of clarity about the zone of possible agreement or appropriate standards for agreement) and 2) the presence of "gender triggers" (i.e., features of the context that make gender relevant and salient, such as the gender [in]congruence of a negotiating role). They theorized that ambiguity would increase the potential for gender triggers to influence negotiation performance.

The specific gender trigger they tested was advocacy role (i.e., negotiating for oneself alone versus for someone else). They hypothesized that advocacy role would moderate women's performance because self-advocacy violates idealized norms of femininity whereas other-advocacy fulfills them. Employing archival data on salary outcomes and lab-based negotiation scenarios, they showed that greater structural 
ambiguity increased gender differences favoring men in competitive bargaining and that, with high structural ambiguity, female negotiators performed significantly better advocating for others than for themselves. Advocacy role had no significant effects on male negotiators' performance. More recently, Mazei, Hüffmeier, Freund, Stuhlmacher, Bilke, \& Hertel (2015) reaffirmed these findings in a meta-analysis of 123 tests of gender effects on negotiation performance, showing that the clearest moderators of gender effects in negotiation are structural ambiguity, advocacy, and negotiation experience.

Building on the advocacy research, Hannah, Linda, and Carnegie Mellon doctoral student Lei Lai tested whether women had a stronger social motivation than men to hold back when faced with an opportunity to self-advocate in negotiation because women were more likely than men to encounter social backlash for doing so (Bowles et al., 2007). Across multiple studies, evaluators reported being significantly less inclined to work with a woman if they read or witnessed on video that she negotiated for higher pay as compared to when they read or witnessed the same woman let the opportunity to negotiate pass. This social cost of negotiating was consistently greater for women than for men. Evaluators were less inclined to work with female negotiators because they perceived them as overly demanding and insufficiently nice. The Bowles et al. (2007) article challenged the notion that women simply needed more confidence or skill at negotiating to attain the same rewards as men. The reported effects were replicated and extended by numerous other scholars (e.g., Amanatullah \& Morris, 2010; Amanatullah \& Tinsley, 2012; Duguid \& Thomas-Hunt, 2015), and the paper received the "Most Influential Article Award" in 2015 by the Conflict Management Division of the Academy of Management. Returning to Linda's academic roots, they also published with Carnegie Mellon doctoral student Julia Bear an economic model of how the backlash effect influences women's decision to negotiate (Babcock, Bowles, Bear, 2012).

Hannah and Linda followed up the backlash work with an article in which they tested negotiating strategies that would help women be more effective in compensation negotiations while also overcoming the social costs having self-advocated in a counterstereotypical way. Based on their results, they advocated that women use "relational accounts" in which they try to explain why their negotiating request is legitimate (e.g., appropriate, justified) in the eyes of their counterpart and that they care about their counterpart's perspective. In Lean In (2013), Sheryl Sandberg used this research to motivate her own negotiating advice for women.

When Julia Bear (now a Professor at Stony Brook) started her Ph.D. at Carnegie Mellon, she was interested in conducting research related to gender. The timing was serendipitous: Linda had recently published Women Don't Ask and was an ideal mentor to study effects of gender on negotiation. Linda (together with Laurie Weingart) advised Julia on her dissertation. Since then, Julia and Linda have continued to collaborate with the aim of improving women's outcomes in negotiation.

One important insight stemming from Julia's dissertation research was that the subject of negotiation moderates gender effects (Bear, 2011; Bear \& Babcock, 2012). Julia and Linda published a study in which they took a classic competitive negotiation exercise over the sale of motorcycle headlamps between automobile executives and changed it to a negotiation over lamp-work jewelry beads in the crafts industry. Women's payoffs increased almost 30 percent when they shifted the context from the masculine-stereotyped automobile industry to the more feminine-stereotyped crafts industry (Sebenius, 1996). 
Julia and Linda have subsequently experimented with strategies for closing the gender gap in masculine-stereotypic negotiations. In a series of studies, they showed that it was possible to prime women to be more assertive negotiators. In a masculine prime, they told women assertiveness paid off in negotiation and instructed them to think about times in their lives when being assertive and forceful in their own defense. In a feminine prime, they encouraged women to imagine they were actually negotiating on behalf of a close friend. In both cases, exposure to the primes reduced the gender gap in competitive bargaining performance as compared to the control condition. They showed that the masculine prime actually increased women's sense of fit with the negotiating challenge (e.g., "My skills match the requirements of this negotiation") (Bear \& Babcock, 2017). Julia and Linda have a chapter forthcoming on "Gender Differences in Negotiation" in the new Negotiator's Fieldbook (Bear \& Babcock, in press).

The community of negotiation researchers that Linda has inspired extends beyond her direct collaborators. Linda's book and the research projects described above inspired a long slate of other negotiation researchers to take up questions of gender in negotiation, including Emily Amanatullah, Carol Kulik, Margaret LaSalle, Ed Miles, Micheal Morris, Mara Olekalns, and Cathy Tinsley. Numerous scholars from others fields have been inspired to study women's propensity to negotiate (e.g., Artz, Goodall, \& Oswald, 2016; Greig, 2008; Leibbrandt \& List, 2014; Rosenblat, 2008). Linda has also been an intellectually engaging and warmly supportive colleague to other leaders in the study of gender in negotiation, such as Laura Kray and Alice Stuhlmacher.

In addition to publishing and inspiring numerous academic articles and to writing her original path-breaking book, Linda has engaged in a heroic amount of public outreach to raise women's negotiating aspirations, increase their propensity to ask for what they want, and enhance their effectiveness at the bargaining table. With Sara Laschever, Linda published a second practice-oriented book entitled, Ask for It: How Women Can Use Negotiation to Get What They Really Want (Babcock \& Laschever, 2008). Coincident with both sets of book publications, Linda co-authored practitioner-oriented articles, such as "Nice Girls Don't Ask" in Harvard Business Review (Babcock, Laschever, Gelfand, Small, 2003) and "First You Have to Ask" in the Program on Negotiation at Harvard Law School's Negotiations Newsletter (Babcock \& Laschever, 2004). She later published an additional Negotiations Newsletter thought piece on "What Happens When Women Don't Ask" (Babcock, 2008) and a column in the New York Times entitled, "Women, Repeat This: Don't Ask, Don't Get" (Babcock, 2008).

When she started her original book project, Linda used to kid —only half jokingthat she wanted to write an academic book she could talk about on the Oprah Winfrey Show. We are not sure if she made it on television with Oprah, but, to this day, Women Don't Ask is praised and promoted on Oprah.com. For the book tour for Women Don't Ask, Linda invested in media training and did her best to respond to every media request-from major television and cable programs with millions of viewers to national newspapers and radio broadcasts to local journalists across the United States and around the world. She also took the time to respond to hundreds of women who heard her message and reached out to her personally with their own stories. She has done countless presentations to audiences ranging from faculty and students to corporate executives, young girls and the White House. 
To further enhance her potential for outreach, Linda founded and remains the faculty director of the Program for Research and Outreach on Gender Equity in Society (PROGRESS), whose mission is to develop tools to teach women and girls how to harness the power of negotiation (see http://progress.heinz.cmu.edu). Their work included a partnership with the Girl Scouts to offer a skills badge in negotiation called, "Win-Win: How to Get What You Want." Linda also leads the Carnegie Mellon Leadership and Negotiation Academy for Women, which is a six-month executive program she co-founded with executive coach M. J. Tocci to develop critical leadership skills through the lens of negotiation. It was the 2017 LEAD Award Winner for Top Executive Education Program in Leadership and Organizational Development presented by HR.com.

Finally, there are meaningful ways in which the Linda's public advocacy and research from the community of negotiation scholars she fostered have contributed to public policy. For example, in 2014, the Obama Administration issued a series of Executive Orders requiring greater pay transparency from federal contractors and prohibiting federal contractors from discriminating against employees or job applicants who inquire about, discuss, or disclose compensation. Similarly, the recent Pennsylvania Senate Bill 241 to strengthen PA Equal Pay Law calls for increased pay transparency and prohibitions on retaliation against employees who ask about or discuss wages. In 2015, Boston Mayor Marty Walsh launched a five-year initiative with American Association of University Women to offer free salary negotiation workshops to women with the goal of training half of Boston's working women. In 2016, the Harvard Mediation \& Negotiation Project launched online negotiation skills training for women in community colleges sponsored by the White House, U.S. Department of Labor and the U.S. Department of Education. These are some examples of how the research community and public discussion of gender in negotiation that Linda inspired is now reflected in equal-pay policies and programming and bettering the lives of innumerable women.

\section{Gender and participation in non-promotable tasks}

As Linda's research shows, women's negotiating is equivalent to that of men when negotiating on behalf of others, but women are not always the most forceful negotiators for themselves. In a brilliant keynote address that Linda gave at the 2016 Judgment and Decision Making meeting, she provided evidence suggesting that, despite her deep knowledge of the phenomenon, she might nevertheless not have always been the best negotiator for herself. In her address, she described a typical day in her life, which started with an 8:30am IRB (Institutional Review Board) meeting, followed by a 10:30am Leadership Committee meeting and a seminar at noon, followed by an Academy meeting at $2 \mathrm{pm}$, a research meeting at 2:30pm, an hour to work on the review of a colleague and finally, a Ph.D. student meeting at 4:30pm. Was this really the kind of day she was dreaming of when she joined academia? Indeed, it was not, and even less so, when she realized what a typical day of a male colleague of hers (amusingly, a coauthor on this piece) looked like: research followed by research followed by more research, interrupted by the lunch seminar, to then be followed by more and more research in the afternoon, concluding with the Ph.D. student meeting that Linda also attended.

This was a wake-up call for her to study the typical days of male and female faculty more closely. She reached out to her female colleagues and formed a club to explore further why women tended to spread themselves so thinly. It was called: "I just can't say no." Their 
experiences mirrored the evidence reported by Misra, Lundquist, Holmes, Agiomavritis (2011) that female faculty spent 7.5 fewer hours on research per week and 4.6 more hours per week on university service than male faculty. However, nobody quite knew where this differences came from.

Being an experimentalist concerned about causal inference, Linda took the question to the lab. Together with Maria Recalde (IFPIR), Lise Vesterlund (Pittsburgh) and Laurie Weingart (Carnegie Mellon), who had also suffered from what the team later named engagement in "non-promotable tasks," they designed a clever experiment to better understand why this was happening (Babcock, Recalde, Vesterlund and Weingart, 2017). To be clear, non-promotable tasks are things you do that are good for you and others (e.g., your institution), that many people, including you, could do (e.g., all professors), that everyone wants to be done yet prefers for someone else to take on (e.g., serving on an administrative committee) and that typically do not show up on your performance evaluation.

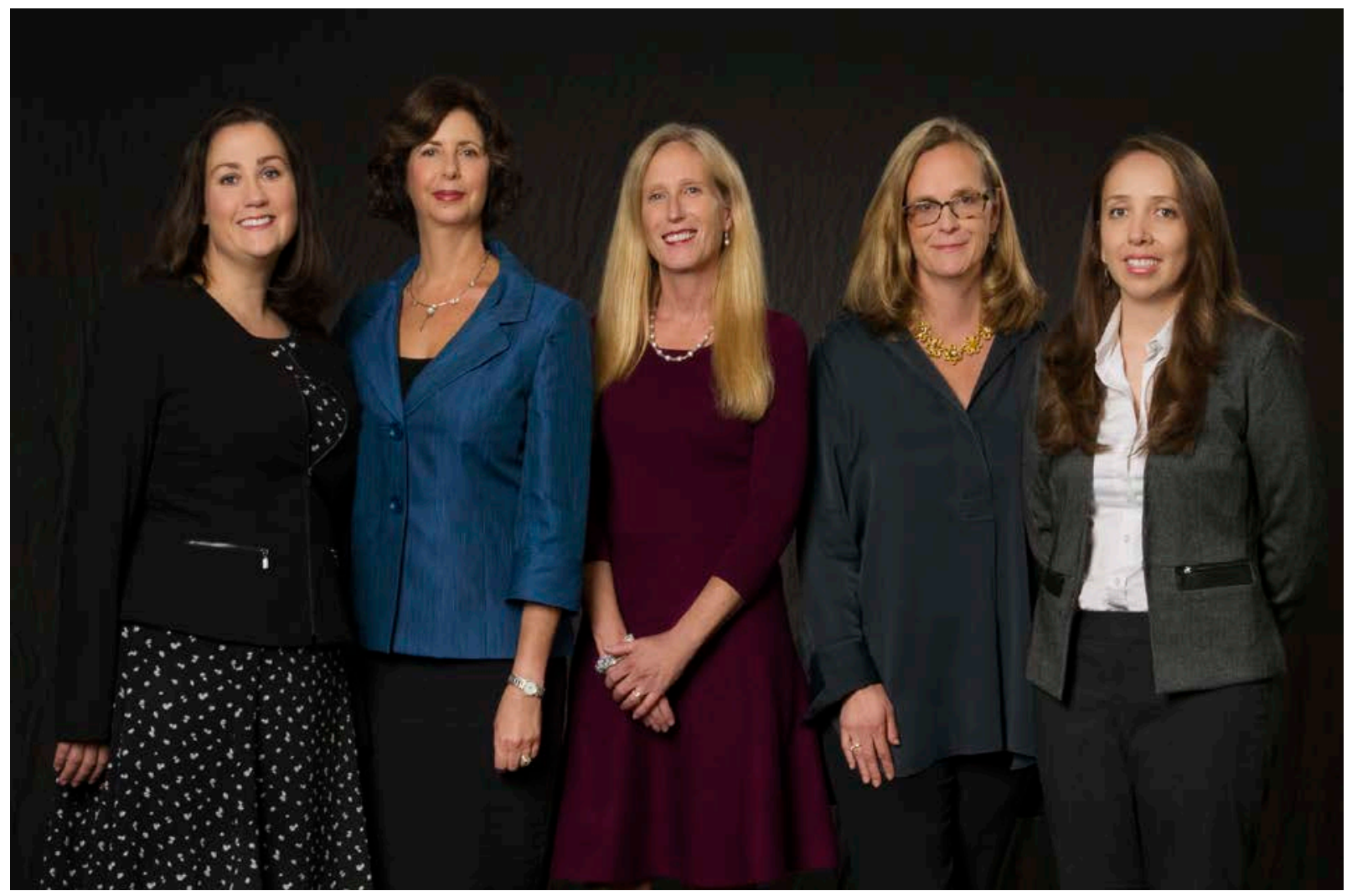

Figure 4: Linda (center, 2016) with coauthors (from left to right) Amanda Weirup, Laurie Weingart, Lise Vesterlund, and Maria Recalde

In all likelihood, female faculty are more likely to be asked to engage in such "nonpromotable tasks." After all, academics are the kind of people who value diversity and thus, would like to have at least one, and ideally more, woman on every committee. Given the low numbers of tenured women in most disciplines, and certainly in Linda's, economics, 
women will end up being asked more often. But holding the ask constant, do women also say "yes" more often?

The research team set out to design an experiment that would capture the incentives we face when asked to undertake a task that we would benefit from, but which we would prefer leaving to somebody else. Of course, non-promotable tasks are not just prevalent in academia but, really, everywhere. Most professionals would prefer someone else organizing the monthly speaker series, mentoring, say, the first-year associates in a law firm, or spending time with and evaluating the consulting firm's summer associates. In all likelihood, most of them benefit from great talks and appreciate wonderful future colleagues but would rather not put in the time.

To mimic such environments, participants in the laboratory experiment were assigned to groups and asked to engage in a task where all were better off if one group member volunteered to take on a costly assignment, making everyone better off. In contrast to the traditional prisoner's dilemma game, volunteering did not quite mean falling on one's sword. As soon as a person stepped up, everyone was better off than if nobody was willing to volunteer including the volunteering party-only that the freeriders' benefits were four times the size of the people stepping up. Group members had two minutes to choose what to do, deciding individually and anonymously in their experimental cubicles. The clock kept ticking until someone volunteered or the time was up and everyone was worse off without the commonly valued good being provided.

Women were significantly more likely than men to volunteer. Interestingly, however, this pattern only prevailed in mixed-sex groups. When in same-sex groups, women and men were about equally willing to volunteer, with men more likely to volunteer than in mixed-sex groups and women less likely to volunteer than in mixed-sex groups. Everyone, including the women, expected women to volunteer more than men. Accordingly, men could afford to dial down their contributions in mixed-sex but not in all-male groups when the opposite was true for women. They had to dial up their contributions in mixed-sex groups but hoped for other women to carry the water in all-female groups.

People had stereotypical beliefs expecting women to do more for the collective than men, and women lived up to these expectations. Those familiar with what the evidence on "shifting standards" (e.g., Biernat et al., 2002) will not be surprised by this finding. We hold ourselves and others to different standards, the standards that conform to the identity group we belong to or most associate with in a given moment, and such gendered norms can turn from describing the state of the world to prescribing what acceptable behavior looks like. Women should be warm, cooperative and caring while men should be tough, competitive and powerful (e.g., Rudman, 1998). Not surprisingly, this pattern does not only affect the supply side but also the demand side. When given the opportunity to ask someone to volunteer in mixed-sex groups, the experimental participants were also more likely to ask women.

What can be done about something that can easily turn into a vicious circle where those stereotyped to be more cooperative end up contributing more than their fair share because they are asked to do so more often and because they say "yes" more often? Should women learn to say "no"? Given Linda's joint work with Hannah and Lei Lai (e.g., Bowles et al., 2007), this is likely a bad idea as women tend to face negative repercussions or "social backlash" for saying "no." In addition, of course, organizations need their employees to 
engage in non-promotable tasks, serve on committees, take guests to dinner and run speaker series.

Harvard Kennedy School, where one of the authors, Bohnet, served as academic dean for a few years, took these insights to heart. The school wanted to make the invisible visible-by counting, measuring, and rewarding people who make contributions relevant to the institution. Still a much loved but also hotly debated practice is that a faculty member receives points for teaching and administrative tasks such as, e.g., committee work. Faculty have substantial flexibility in how they want to meet these obligations. Some might end up teaching more than the minimal requirement, others might spend more time on search, appointments or IRB-committees. A full-time faculty member is expected to contribute 100 points (with a margin of error of 10 percent plus or minus); over-contributors receive extra compensation and under-contributors are asked to adjust either their time status or their pay.

While not everything is quantifiable, and the school is quite concerned about crowding out of intrinsic motivation, the point system has three huge advantages: it provides incentives for people to deliver the public goods everyone benefits from, brings inequities related to service activities out into the open and allows faculty to trade off tasks they are less good at for service activities they are better at. For example, if the Kennedy School had not measured public service, the administration would not have known that the only black female professor was mentoring all African American women on campus nor that women were overtaxed by the desire to ensure that there was at least one on every administrative committee. What does not get measured, does not count, as the saying goes, and as Bohnet argues in her recent book, What Works: Gender Equality By Design, what does not get measured, cannot be fixed (Bohnet, 2016).

Ironically, given her research on nonpromotable tasks, Linda was the first to read Bohnet's book manuscript and offer extremely helpful comments. Although it may have lost her more points in the "I can't say no" club, it illustrates the quality of giving that all of so admire in Linda.

\section{Closing Comments}

NCMR is respected for connecting theory and practice, and Linda's ability to do exactly that was what led to her receiving the IACM Jeffrey Rubin Theory to Practice Award. One measure of practice is the ability to use theory to advise others. Another is whether you can incorporate good research results into your own behavior. Many advice-giving professions are known for their practitioners' failure to follow their own counsel. Psychiatrists (as well as their children) are famously maladjusted; doctors make bad patients; clergy are corrupt, and, perhaps less well known outside of business school circles, academics who teach negotiations are not known for their personal skills at the art and science of negotiation. Linda is a prominent exception to this rule. While her research suggests that many people suffer from self-serving bias, she does not. She serves others, making the world a better place, including for the authors of this paper.

However, perhaps the situation is not so simple. While her research shows that women should ask and say no more often, we cannot report that she follows her own advice. For example, perhaps she didn't show the greatest negotiating skills in agreeing to take the position to head of the academic department that includes Babcock and 
Loewenstein, but Loewenstein can attest to her transformative influence. Assuming leadership of a complicated interdisciplinary department, Linda's headship ushered in a period of tranquility, productivity and harmoniousness, not only within the department itself, but between the department and other units on campus. Linda's brilliance as a negotiator comes not from her ability to "get to yes," or to expand the mythical fixed pie (with apologies to the senior author of this piece) but, in a Mary Poppins fashion, to make the parties unaware that they are even engaged in a negotiation. Perhaps in doing so she has a highlighted a great topic for future research - how to negotiate effectively by reducing the salience of the concept of negotiating to the other side?

Indeed, the four of us have tried to adopt the "Linda way." When Loewenstein asked whether Bazerman, Bohnet and Bowles would participate in this article, they just said yes. No questions asked. When the authors allocated the writing, it came naturally, without a negotiation. And when it came to the final touches and managing the time crunch, people jumped in as needed to make it all work. Yes, her excellent scholarship made it easy for us to write about her work but truly, it was not the go-getter that had the final word. We wanted to do this because Linda is a wonderful human being - a do-gooder who has inspired us all.

\section{Some questions for our friend}

It has become a tradition to follow celebrations of Rubin award candidate papers with a short back-and-forth with the recipient. Here, we ask Linda to answer a few personal and academic questions to help us, and the reader, gain a deeper insight into the life and mind of a truly remarkable academic.

(1) Linda, can you tell us a bit about how your family background contributed to your development as a scholar?

I was raised in an academic family; my father was a professor at Caltech. Growing up, I thought that he had the perfect job—conducting interesting and important research in his lab, teaching wonderful students, and mentoring graduate students. He truly loved his job and it was infectious. This really made an impression on me, and when I got interested in economics in college it became clear to me that I would also become a professor. It's the greatest job in the world.

(2) In personal conversations with you, gender rarely comes up as an issue. How did you get so interested in this angle on negotiations?

You're kidding, right? It seems like that's all I ever talk about these days! I've been obsessed with gender issues since the late 1990s. It all started when a group of female PhD students approached me to tell me that they thought the school was discriminating against them. The male students in the program were teaching courses and the female students had been assigned to 
be TAs. When I went to investigate with the Associate Dean about it (and that person is my husband!), he said that all of the male students had come to him to ask to teach because it would be very useful for the job market. He said to me: “The women didn’t ask." And my obsession began.

(3) Have you gained any insights into your research, or into translations of it into practice from being the parent of a (now college-age) daughter?

That's actually why I started PROGRESS, I knew that I could teach young girls to negotiate based upon my daughter being an excellent negotiator. When she was 5 she decided that she wanted to spend the summer at "sleep-away" horse camp in a neighboring state. Of course, I said absolutely not. And we could have gotten into a fight over it with her screaming that she wanted to go and me countering that she was too young. But that didn't happen because after the first time I said "no" she said to me, "I think I know what your concerns are" (those were her exact words). She then articulated to me her thoughts about my concerns (which were quite accurate) and devised a plan to address them. Of course she ended up going to camp and absolutely loved it. She turned what could have been a fight into a constructive negotiation. Proof of concept!

(4) What are some of the principles that guide you in administrative roles, such as serving as the acting dean of the Heinz School of Public Policy or the head of the Department of Social and Decision Sciences.

I use my negotiation skills a lot. It is very helpful to think about interests rather than positions and to not be afraid of conflict. It makes it easier that I have wonderful colleagues and ones who really support me even if they don't always agree with my decisions. 


\section{References}

Amanatullah, E. T., \& Morris, M. W. (2010). Negotiating gender roles: Gender differences in assertive negotiating are mediated by women's fear of backlash and attenuated when negotiating on behalf of others. Journal of Personality and Social Psychology, 98(2), 256-267. doi:10.1037/a0017094

Amanatullah, E. T., \& Tinsley, C. H. (2012). Punishing female negotiators for asserting too much or not enough: Exploring why advocacy moderates backlash against assertive female negotiators. Organizational Behavior and Human Decision Processes, 120(1), 110-122. doi:http://dx.doi.org/10.1016/j.obhdp.2012.03.006

Artz, B., Goodall, A., \& Oswald, A. J. (2016). Do women ask? . IZA Discussion Papers. Babcock, L. (2008). What happens when women don't ask. Negotiation, 11(96), 1-4. Babcock, L. (2008). Women, Repeat This: Don't Ask, Don't Get. New York Times, BU19.

Babcock, L., Benedict, M. E., \& Engberg, J. (1998). Pittsburgh Labor Market Adjustments In The 1980S: Who Gained and Who Lost? Journal of Urban Affairs, 20(1), 53-68. doi:10.1111/j.1467-9906.1998.tb00410.x

Babcock, L., Bowles, H. R., \& Bear, J. (2012). A model of when to negotiate: Why women don't ask. In G. E. Bolton \& R. T. A. Croson (Eds.), The Oxford Handbook of Economic Conflict Resolution (pp. 313-331). New York: Oxford University Press.

Babcock, L., Engberg, J., \& Glazer, A. (1997). Wages And Employment In Public-Sector Unions. Economic Inquiry, 35(3), 532-543. doi:10.1111/j.1465-7295.1997.tb02030.x

Babcock, L., Engberg, J., \& Greenbaum, R. (2005). Wage spillovers in public sector contract negotiations: the importance of social comparisons. Regional Science and Urban Economics, 35(4), 395-416. doi:10.1016/j.regsciurbeco.2004.05.001

Babcock, L., Gelfand, M., Small, D., \& Stayn, H. (2006). Gender differences in the propensity to initiate negotiations. In D. D. Cremer, M. Zeelenberg, \& J. K. Murnighan (Eds.), Social Psychology and Economics (pp. 239-262). Mahwah, NJ: Lawrence Erlbaum.

Babcock, L., \& Laschever, S. (2003). Women Don't Ask: Negotiation and the Gender Divide. Princeton, NJ: Princeton University Press.

Babcock, L., \& Laschever, S. (2004). First you have to ask. Negotiation, 3-5.

Babcock, L., \& Laschever, S. (2007). Women don't ask: The high cost of avoiding negotiation-and positive strategies for change. New York: Bantam Books.

Babcock, L., \& Laschever, S. (2008). Ask for it: How women can use negotiation to get what they really want. New York: Bantam Books.

Babcock, L., Laschever, S., Gelfand, M., \& Small, D. (2003). Nice girls don't ask. Harvard Business Review, 81(10), 14-15.

Babcock, L., Loewenstein, G., Issacharoff, S., \& Camerer, C. (1995). Biased Judgments of Fairness in Bargaining. The American Economic Review, 85(5), 1337-1343.

Babcock, L., M.P. Recalde, L. Vesterlund and L. Weingart (2017). Gender Differences in Accepting and Receiving Requests for Tasks with Low Promotability. American Economic Review 107 (3), 714-747.

Babcock, L., \& Olson, C. A. (1992). The Causes of Impasses in Labor Disputes. Industrial Relations,31(2), 348-360. doi:10.1111/j.1468-232x.1992.tb00313.x

Babcock, L., \& Taylor, L. J. (1996). The Role of Arbitrator Uncertainty in Negotiation Impasses. Industrial Relations, 35(4), 604-610. doi:10.1111/j.1468-

232x.1996.tb00424.x 
Bear, J. B. (2011). Passing the buck: Incongruence between gender role and topic leads to avoidance of negotiation. Negotiation and Conflict Management Research, 4(1), 4772.

Bear, J. B., \& Babcock, L. (2012). Negotiation topic as a moderator of gender differences in negotiation. Psychological Science, 23(7), 743-744.

Bear, J.B., \& Babcock, L. (2017). Negotiating femininity: Gender-relevant primes improve women's economic performance in gender role incongruent negotiations, 41(2), 163-174.

Bear, J. B., \& Babcock, L. (in press). Gender differences in negotiation. In A. K. Schneider \& C. Honeyman (Eds.), The negotiator's fieldbook: The desk reference for the experienced negotiator.

Biernat, M. and T.K. Vescio (2002). She swings, she hits, she's great, she's benched: Implications of gender-based shifting standards for judgment and behavior. Personality and Social Psychology Bulletin, 28, 66-77.

Bohnet, I. (2016). What Works: Gender Equality By Design. Cambridge: Harvard University Press.

Bowles, H. R., Babcock, L., \& Lai, L. (2007). Social incentives for gender differences in the propensity to initiate negotiations: Sometimes it does hurt to ask. Organizational Behavior and Human Decision Processes, 103(1), 84-103.

Bowles, H. R., Babcock, L., \& McGinn, K. L. (2005). Constraints and triggers: Situational mechanics of gender in negotiation. Journal of Personality and Social Psychology, 89(6), 951-965.

Burt, R. S. (1998). The gender of social capital. Rationality and Society, 10(1), 5-46. doi:10.1177/104346398010001001

Byrnes, J. P., Miller, D. C., \& Schafer, W. E. (1999). Gender differences in risk taking: a metaanalysis. Psychological Bulletin, 125(3), 367-383.

Camerer, C., Babcock, L., Loewenstein, G., \& Thaler, R. (1997). Labor supply of New York City cabdrivers: One day at a time. The Quarterly Journal of Economics, 112(2), 407441.

Curhan, J. R., Neale, M. A., Ross, L., \& Rosencranz-Engelmann, J. (2008). Relational accommodation in negotiation: Effects of egalitarianism and gender on economic efficiency and relational capital. Organizational Behavior and Human Decision Processes, 107(2), 192-205.

Duguid, M. M., \& Thomas-Hunt, M. C. (2015). Condoning Stereotyping? How Awareness of Stereotyping Prevalence Impacts Expression of Stereotypes. Journal of Applied Psychology, 100(2), 343-359.

Eagly, A. H. (1987). Sex differences in social behavior: A social-role interpretation. Hillsdale, NJ: Erlbaum.

Greig, F. (2008). Propensity to negotiate and career advancement: Evidence from an investment bank that women are on a 'slow elevator.'. Negotiation Journal, 24(4), 495-508.

Kray, L. J., \& Babcock, L. (2006). Gender in negotiations: A motiated social cognitive analysis. In L. Thompson (Ed.), Negotiation theory and research (pp. 203-224). New York: NY: Psychology Press. 
Kray, L. J., \& Thompson, L. (2004). Gender stereotypes and negotiation performance: A review of theory and research. In B. M. Staw \& R. Kramer (Eds.), Research in Organizational Behavior Series (Vol. 26, pp. 103-182). Greenwich, CT: JAI Press.

Leibbrandt, A., \& List, J. A. (2014). Do women avoid salary negotiations? Evidence from a large-scale natural field experiment. Management Science, 61(9), 2016-2024.

Loewenstein, G., Issacharoff, S., Camerer, C. \& Babcock, L. (1993). Self-serving assessments of fairness and pretrial bargaining. Journal of Legal Studies, 22, 135-159.

Magee, J. C., Galinsky, A. D., \& Gruenfeld, D. H. (2007). Power, propensity to negotiate, and moving first in competitive interactions. Personality and Social Psychology Bulletin, 33(2), 200-212.

Major, B., McFarlin, D. B., \& Gagnon, D. (1984). Overworked and underpaid: On the nature of gender differences in personal entitlement. Journal of Personality and Social Psychology, 47(6), 1399-1412.

Mazei, J., Hüffmeier, J., Freund, P. A., Stuhlmacher, A. F., Bilke, L., \& Hertel, G. (2015). A metaanalysis on gender differences in negotiation outcomes and their moderators. Psychological Bulletin, 141(1), 85.

Misra, J., Lundquist, J.H., Holmes, E., Agiomavritis, S. (2011). The Ivory Ceiling of Service Work. Academe 97(1), 22-26.

Rosenblat, T. S. (2008). The beauty premium: Physical attractiveness and gender in dictator games. Negotiation Journal, 24(4), 465-481.

Rudman, L. A. (1998). Self-promotion as a risk factor for women: The costs and benefits of counterstereotypical impression management. Journal of Personality and Social Psychology, 74(3), 629-645.

Sandberg, S. (2013). Lean in: Women, work, and the will to lead. New York: Alfred A. Knopf.

Sebenius, J. K. (1996). Mapletech-Yazawa (A) and (B). Boston: HBS Press.

Sherman, A. C., Higgs, G. E., \& Williams, R. L. (1997). Gender differences in the locus of control construct. Psychology and Health, 12(2), 239-248.

Small, D. A., Gelfand, M., Babcock, L., \& Gettman, H. (2007). Who goes to the bargaining table? The influence of gender and framing on the initiation of negotiation. Journal of Personality and Social Psychology, 93(4), 600-613. doi:10.1037/0022-3514.93.4.600

Walters, A. E., Stuhlmacher, A. F., \& Meyer, L. L. (1998). Gender and negotiator competitiveness: A meta-analysis. Organizational Behavior and Human Decision Processes, 76(1), 1-29. 